\title{
A Significant Approach to Search Potent Lead of Coumarin Derivatives via Computational and Pharmacological Screening For Anticancer Activity: Hypothesis
}

\author{
Vinit Raj* \\ Department of Pharmaceutical Sciences, Babasaheb Bhimrao Ambedkar University, India
}

Submission: January 30, 2017; Published: February 20, 2017

"Corresponding author: Vinit Raj, Department of Pharmaceutical Sciences, Babasaheb Bhimrao Ambedkar University, Vidya Vihar, Rae Bareli Road, Lucknow 226025, India, Tel: +918859383897; Email: raj.vinit24@gmail.com

Abstract

Cancer is the major cause of death worldwide. There are many availability of diagnosis for the cancer such as include chemotherapy and surgery. But due to lack of specificity towards the particular cancer, that became the hot topic in the research area now-a-days. In addition, to reduce the cost and adverse side effect by using the new computation techniques to discover the new lead, providing the better hypothesis for the specificity towards cancer cell. In that article, coumarin derivatives can be help to provide significant hypothesis to develop and discover potential lead towards cancer cell.

Keywords: Cancer; Coumarin derivatives; Computation modeling; Hypothesis

\section{Introduction}

Cancer is third most [1] common worldwide where high percentage of deaths occurs annually. The majority of patients with cancer die within a year after diagnosis. The present treatment to cure from cancer include chemotherapy and surgery, however the synthetic chemotherapeutic drugs have several side effect. Searching of newer anticancer agents is the hot topic in the research area now-a-days [1]. Therefore, coumarin derivatives have more importance as they have versatile biological properties particularly they have been found to be exhibited anticancer properties.

Hence, cancer is a burgeoning major public health issue worldwide and economic burden as well as a threat to society which is increasing the risk of human affliction. In 2008, 2•45 million people were examined which affected with cancer and 1.23 million died because of cancer in the 27 countries of the European Union (EU) [2-3]. From these surveys indicated that the most common cancer were breast, colorectal, lung, and prostate cancers founded. Another survey, particularly to emerging countries, China (1 350695000 people), India (1 236 686732 people), and Russia (143533000 people) together account for nearly $40 \%$ of the world's population affected with cancer [4].
Coumarin are lactones of hydroxycinnamic acid (2H-1benzopyran-2-one) widely distributed in plants and that can also be found in fungi and bacteria. About 1.300 coumarin have been isolated from these natural sources as a single nucleus or combined with sugars or acids. This class of compounds presents many pharmacological applications as anti-inflammatory, antispasmodic, antioxidant and antitumor activities, depending on its substitution patterns [4-6].

In this study, we would focus on developing a new scaffold which can be able to have potent activation effect. During searching of new lead for COX-2, IL-2, IL-6 and caspase 3/8 target, coumarin derivatives would be play essential role to the treatment of cancer.

\section{Literature Review}

Misra et al. (2013) suggested that Cyclooxygenase-2 (COX-2) and 5-lipoxygenase (5-LOX) enzyme have been found to play a role in promoting growth in cancer cell lines. Garth R Anderson et al. (1981) give the views in cancer tissues typically exhibit a 2 to 3 fold increase in glycol tic enzymes and LDH activity. Zarghami et al. (1995) suggested that Creative kinase is an important enzyme involved in cellular energy homeostasis High level of 


\section{Organic and Medicinal Chemistry International Journal}

CK have also been observed in some primary cancerous tissues, metastatic lesions and sera with various cancers. Fernandez et al. (2004) state that cytokines are large group of polypeptide produce by wide variety of cells. T lymphocytes are major source of cytokines production. Upon activation they differentiate in two form of helper (Th) cell according to their cytokines profile.

Wang et al. (2010) suggested that COX-2 represents an important molecular target in cancer prevention and treatment. Cyclooxygenase- 2 expression is regulated at both the transcriptional and post-transcriptional levels. It is well established that the COX-2 transcription can be regulated by various transcription factors such as nuclear factor-kB. Olive et al. (2005) Caspase are the member of the aspartamespecify cysteinyl protease family. Caspase-3 activated in the mitochondrial pathway by its upstream regulator, active caspase-9.

\section{Research Envisaged}

Based on the previous literature survey, the important pharmacophore for anticancer therapy are hydrophobic aryl ring (Ar), hydrogen bonding domain (HBD), and an electron-donor group, another distal hydrophobic site.

We proposed coumarin derivatives which might have anticancer activity which contains all the above mentioned pharmacophore. After pharmacophore based virtual screening from the drug data bank via bioinformatics study, ligand will be selected. Further, the hypothesis would be proved using in vivo studies for cancer. Therefore, the main objectives of our project are to screen, investigate and explore the appropriate mechanism for the anticancer activity of coumarin derivatives.

\section{Plan of Work}

I. Litature survey and designed scheme.

II. Virtual Screening of coumarin derivatives from data banks.

III. Computational study for prediction and assumption of hypothesis.
IV. To evaluate anticancer activity of best lead derivatives.

V. In-vitro screening against cancer cell line.

VI. In-vivo study (in vivo cancer model).

VII. PCR and Western blotting in order to explore the molecular mechanistic of ligand.

VIII. Pharmacokinetic study and Statistic analysis of data.

\section{Conclusion and Future Prospective}

From the Ancient time, coumarin has been possessed potential anticancer activity. Thereby, in this study, the hypothesis tried to search the potential lead, further which would be elucidated their molecular mechanistic in order to identified potent target to prevent the cancer. After the acceptance and prove the assumption the lead would be further study for argumentation their potency towards the cancer.

\section{Reference}

1. Krammer PH (1999) CD95(APO-1/Fas)-mediated apoptosis: live and let die. Adv Immunol 71: 163-210.

2. Wei Hu, John J Kavanagh (2003) Anticancer therapy targeting the apoptotic pathway. lancet oncol 4(12): 721-729.

3. Ramon Luengo Fernandez, Jose Leal, Alastair Gray, Richard Sullivan (2013) Economic burden of cancer across the European Union: a population-based cost analysis. Lancet Oncol 14(12): 1165-1174.

4. Paul E Goss, Kathrin Strasser Weippl (2014) Challenges to effective cancer control in China, India, The Lancet Oncology Commission and Russia. Lancet Oncol 15(5): 489-538.

5. R F Rodrigues, A K Tashima, RM S Pereira, R S Mohameda, F A Cabral (2008) Coumarin solubility and extraction from emburana (Torresea cearensis) seeds with supercritical carbon dioxide. J Supercrit Fluids 43(3): 375-382.

6. Felipe Vitorio, Thiago Moreira Pereira, Rosane Nora Castro, Guilherme Pereira Guedes, Cedric Stephan Graebin, et al. (2015) Synthesis and mechanism of novel fluorescentcoumarin-dihydropyrimidinone dyads obtained by the Biginelli multicomponent reaction. New J Chem 39(3): 2323-2332.

Your next submission with Juniper Publishers
will reach you the below assets
- Quality Editorial service
- Swift Peer Review
- Reprints availability
- E-prints Service
- Manuscript Podcast for convenient understanding
- Global attainment for your research
- Manuscript accessibility in different formats
( Pdf, E-pub, Full Text, Audio)
- Unceasing customer service
Track the below URL for one-step submission
https://juniperpublishers.com/online-submission.php

